\title{
The Influence of Metakaolin from Saaba (Burkina Faso) over Physico-Mechanical and Durability Properties of Mortars
}

\author{
Fabrice Ntimugura, Seick Omar Sore, Latifou Bello, Adamah Messan* \\ Institut International d'ingénierie de l'Eau et de l'Environnement (2iE), Laboratoire Eco-Matériaux de \\ Construction (LEMC), Ouagadougou, Burkina Faso \\ Email: *adamah.messan@2ie-edu.org
}

How to cite this paper: Ntimugura, F., Sore, S.O., Bello, L. and Messan, A. (2017) The Influence of Metakaolin from Saaba (Burkina Faso) over Physico-Mechanical and Durability Properties of Mortars. Open Journal of Civil Engineering, 7, 389-408.

https://doi.org/10.4236/ojce.2017.73027

Received: June 30, 2017

Accepted: August 19, 2017

Published: August 22, 2017

Copyright (๑) 2017 by authors and Scientific Research Publishing Inc. This work is licensed under the Creative Commons Attribution International License (CC BY 4.0).

http://creativecommons.org/licenses/by/4.0/

\begin{abstract}
The paper evaluates the feasibility of reducing clinker in the Portland Cement production using local metakaolin in Burkina Faso. Standardized testing methods have been used for this purpose, and experiments were performed on mortar prisms containing different amounts of metakaolin. Important results about the physical, mechanical and durability characterization of blended mortars were carried out in this study. The obtained results are discussed based on available literature data. These results have shown increased physical and durability properties for blended mortars. Although the mechanical strengths remained relatively low for higher $\mathrm{MK}$ incorporations, the latter grow to surpass these of PC mortars (the reference) at 28, 56 and 90 days of curing. The results in the paper, have confirmed the possibility of using metakaolin to partially substitute cement, a possibility to reduce the $\mathrm{CO} 2$ production by the cement industry in Burkina Faso.
\end{abstract}

\section{Keywords}

Calcined clays, Metakaolin, Mortar, Cement, Burkina Faso

\section{Introduction}

The progressive increase of the energy prices over the past decades in Africa, has restrained the availability of the conventional building binder "cement" to the large majority of poor and middle-income countries populations. These same countries, display the highest demographic trends and hence, high decent housing demands. In addition to this cost-related hindrance, the recent environmental considerations of cement production industry (emission of one ton of $\mathrm{CO}_{2}$ 
per ton of cement) motivated the search of "alternatives". The cement industry contributes for up to $5 \%-8 \%$ of global $\mathrm{CO}_{2}$ emissions in 2014 [1].

The potential of Burkina Faso in terms of clayey materials has recently drawn the attention of researchers from varied fields of engineering and technology. These include road construction materials stabilization [2] [3], general building materials (bricks) [4] and water treatment and sanitation applications [5]. Although varied are these areas of research, none has addressed the exploitation of pozzolanic activity of thermally activated clays in hydraulic binders.

In fact, clays with high kaolinite content (kaolin clays) are potential pozzolanas and can be used as supplementary cementitious materials when activated (thermally or chemically). In the geological context of Burkina Faso, most of the kaolin clay quarries are found nearby the tuff-hillsides and are sought to have evolved from them [6]. These kaolin clays, when sintered at temperatures around $500^{\circ} \mathrm{C}-800^{\circ} \mathrm{C}$ produce metakaolin [7]. This material with high content of amorphous silica $\left(\mathrm{SiO}_{2}\right)$ and alumina $\left(\mathrm{Al}_{2} \mathrm{O}_{3}\right)$ reacts with the cement hydration Portlandite $\left(\mathrm{Ca}(\mathrm{OH})_{2}\right)$ to create secondary calcium silicate hydrates (C-S-H) and alumina containing C-A-H and/or C-A-S-H phases [8]. In this study, higher proportions were attempted for the optimization of $\mathrm{CH}$ consumption. In fact, Kostuch et al. [9] have found 20\% MK incorporations necessary for full removal of $\mathrm{CH}$ in concrete at 28 days of curing.

The synthesis of MK by the dihydroxylation/amorphization of kaolin clay is a key step for optimum pozzolanic activity of the resulting material [10]. The influence of heat treatment parameters over the reactivity of MK have been explored extensively [11] [12] [13] [14]. Ambroise et al. [15] have suggested temperatures above $700^{\circ} \mathrm{C}$. Nevertheless, higher temperatures can lead to the recrystallization and formation of mullite and cristobalite non-reactive phases [16] [17] [18]. Raw clays differing in terms of purity, the most accurate heat treatment program should be deduced from individual clay thermal analyses using TG/DTA.

The incorporation of $\mathrm{MK}$ in cement production would have a substantial economic impact and environmental relief in Burkina Faso. In fact, there are no local industries that produce Portland Clinker for its production requires high technology and considerable amount of fuel (energy). Hence, the clinker is imported from the West and Asia, increasing its price. On the environmental point of view, for instance the production of one ton of flash metakaolin only produces 0.098 ton of equivalent $\mathrm{CO}_{2}$ versus 0.913 tons per one ton of PC of type CEM I [19].

Considering the two motivational aspects, this study aims at evaluating the possibility of using the local calcined clay (metakaolin) at high proportions as a partial substitute of clinker in West Africa. Throughout this study, the effect an increasing substitution rate of cement by MK over the physical, mechanical and durability properties of the MK blended cement was explored. The used materials were characterized using the ICP-OES for chemical composition, the $\mathrm{x}$-rays 
diffraction for mineralogy and TG/DTA for thermal analyses.

\section{Materials and Experimental Methods}

\subsection{Materials}

\subsubsection{Cement}

The cement used in this study is a CEM I type locally available cement produced by Cimtogo Company affiliated to the Heidelberg cement industries [20]. Its chemical composition is shown in Table 1 . This cement has an absolute density of 3.1 and Blaine specific area of $3565 \mathrm{~cm}^{2} / \mathrm{g}$. The used cement has the mineralogical composition that reveals $57.7 \%$ C3S, $19.6 \%$ C2S, 7.3\% C3A and 9.4\% C4AF (Table 1). The determined initial setting time according to the EN 196-3 standard [21] is 138 minutes. The mineralogical composition was determined using the X-ray diffraction technique (XRD shown on the Figure 1) and corroborate the chemical composition.

\subsubsection{Sand}

The sand used for the whole experimental program is locally available sand. This material was sieved to $5 \mathrm{~mm}$ and then washed to reduce the fine particles. The granulometric analysis performed according to the NF P 94-056 French Standard [22]. The results showed a Hazen uniformity coefficient of 3.2 with a coefficient of curvature of 0.8 . The bulk density of the sand was found to be 1.58 $\mathrm{g} / \mathrm{cm}^{3}$ while the specific density was $2.7 \mathrm{~g} / \mathrm{cm}^{3}$. The used sand was found to be of high quality with equivalent sand values of $88.58-92$.

Table 1. Chemical, mineralogical composition and physical characteristics of cement and metakaolin.

\begin{tabular}{|c|c|c|c|c|c|}
\hline \multicolumn{3}{|c|}{ A. Chemical composition } & \multicolumn{3}{|c|}{ B. Mineralogical composition (\%) } \\
\hline Oxide (\%) & Metakaolin & Cement & & Metakaolinite & 83.4 \\
\hline $\mathrm{SiO}_{2}$ & 57.85 & 18.6 & Metakaolin & Quartz & 12.8 \\
\hline $\mathrm{Al}_{2} \mathrm{O}_{3}$ & 38.3 & 4.73 & & Ferric oxide & 2.3 \\
\hline $\mathrm{CaO}$ & 0.05 & 59.6 & & Alite & 57.7 \\
\hline $\mathrm{Fe}_{2} \mathrm{O}_{3}$ & 2.3 & 3.11 & & Belite & 19.6 \\
\hline $\mathrm{SO}_{3}$ & $/ /$ & 2.62 & Cement & Aluminate & 7.3 \\
\hline $\mathrm{MgO}$ & 0.09 & 2.57 & & Ferrite & 9.4 \\
\hline $\mathrm{K}_{2} \mathrm{O}$ & 0.23 & 0.26 & \multicolumn{3}{|c|}{ C. Absolute density $\left(\mathrm{g} / \mathrm{cm}^{3}\right)$} \\
\hline $\mathrm{Na}_{2} \mathrm{O}$ & 0.11 & 0.1 & Metakaolin & \multicolumn{2}{|c|}{2.63} \\
\hline $\mathrm{MnO}_{2}$ & 0.01 & 0.085 & Cement & \multicolumn{2}{|c|}{3.1} \\
\hline $\mathrm{TiO}_{2}$ & 0.09 & 0.24 & \multicolumn{3}{|c|}{ D. Specific areas } \\
\hline $\mathrm{P}_{2} \mathrm{O}_{5}$ & 0.02 & 0.47 & Metakaolin & \multicolumn{2}{|c|}{$14.8\left(\mathrm{BET}\right.$ in $\left.\mathrm{m}^{2} / \mathrm{g}\right)$} \\
\hline L.O.I & 1.01 & 8.05 & Cement & \multicolumn{2}{|c|}{3565 (Blaine in $\mathrm{cm}^{2} / \mathrm{g}$ ) } \\
\hline
\end{tabular}




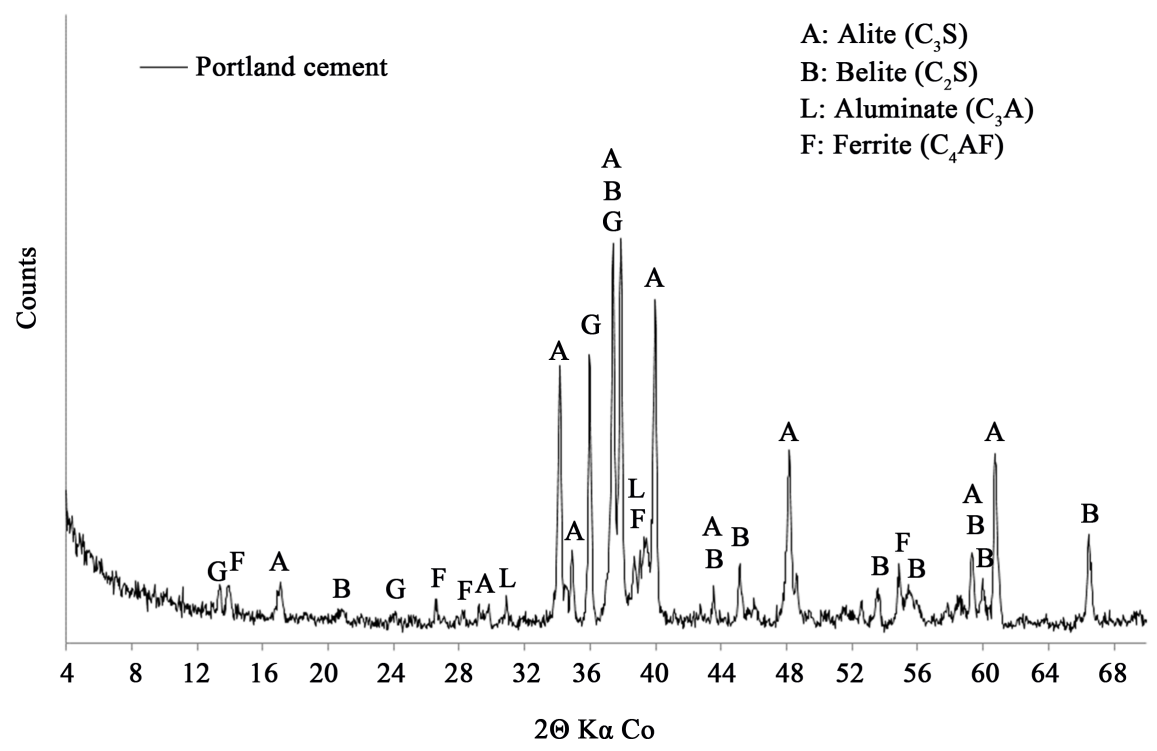

Figure 1. The X-rays diffractogram of the cement.

\subsubsection{Kaolin and Metakaolin from Saaba}

The kaolin clay used in this work was extracted from the quarry of SAABA located in the suburbs of Ouagadougou the capital at coordinates N $12^{\circ} 22.772$ ', W $001^{\circ} 24.634^{\prime}$, and at an average altitude of around $317 \mathrm{~m}$. This material has been used in previous research about synthesis of geopolymer binders based on local materials from Burkina Faso [23]. The heat treatment applied was for a three hours' period at $700^{\circ} \mathrm{C}$ at a $10^{\circ} \mathrm{C} / \mathrm{min}$ rate. The used furnace is an SN 320,177 Nabertherm of a $1200^{\circ} \mathrm{C}$ heating capacity. The obtained Metakaolin was allowed to cool down naturally at the average room temperature of $30^{\circ} \mathrm{C}$ for six hours. The obtained metakaolin was crushed down using a A0091/1 Controlab laboratory electric mill and sieved to 125 microns. The material was then stored in plastic bags to prevent humidity intake. The Figure 2 shows the TG and DTA of the kaolin raw clay. The Figure 3 displays the XRD patters of the studied powders. The particle size of the blended binders' powders i.e. PC (cement) and MK (metakaolin) are shown Figure 4 with $\mathrm{D}_{50}$ of $10 \mu \mathrm{m}$ and $9 \mu \mathrm{m}$ respectively.

\subsection{Experimental Methods}

\subsubsection{Sample Preparation and Mix design}

Mortars preparations have been performed by mixing sand and cement for 2 minutes and adding water (containing the superplasticizer) before mixing for another 2 minutes' period. The mixing machine used is a 10,031.5 Controlab automatic mixer. Afterwards, they were cast into prismatic $40 \times 40 \times 60 \mathrm{~mm}^{3}$ steel molds using a standardized 65-L0012/E Controls shock table machine. The mortars were covered with plastic bags to prevent water losses. After a 24 hours' period, the mortars were demolded and immediately placed into water in the laboratory conditions at $20^{\circ} \mathrm{C}$ and $60 \mathrm{RH}$ till test days (2, 7, 28, 56 days). The mortars prepared for durability testing were cast into the cylindrical molds of 50 


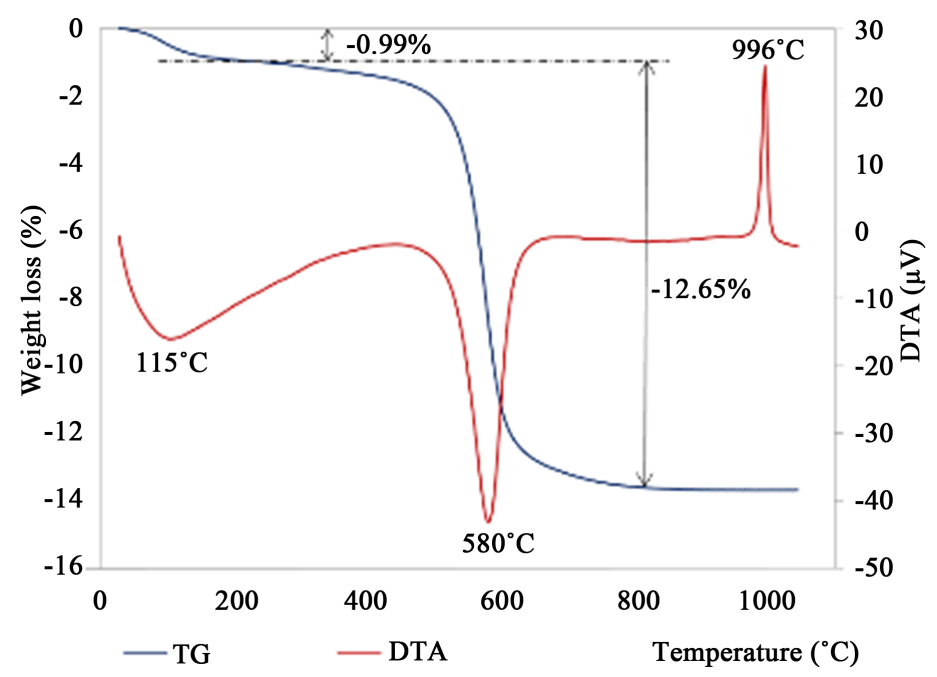

Figure 2. The TG /DTA of the kaolinite clay from SAABA [23].

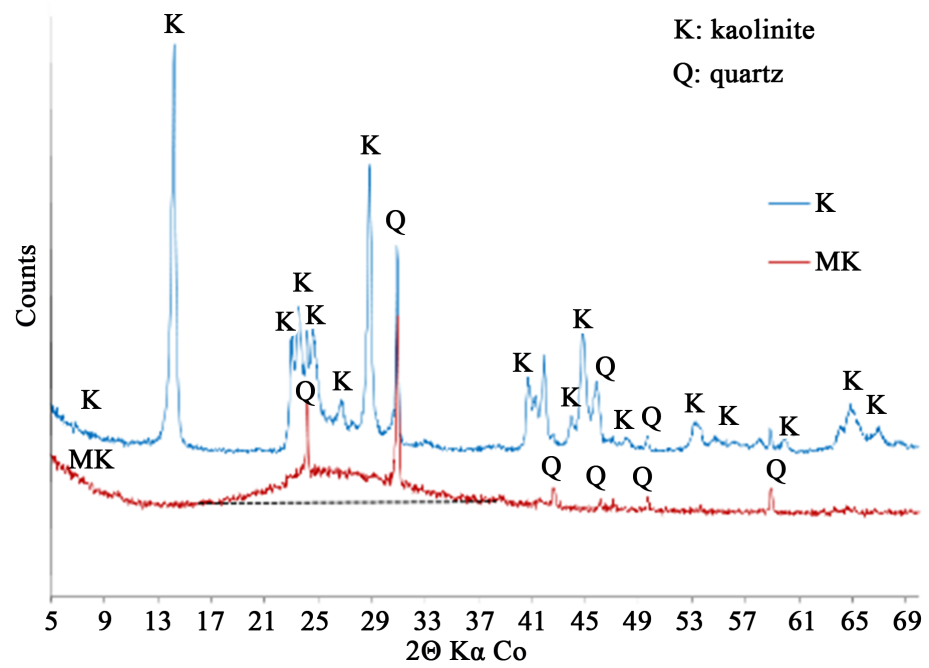

Figure 3. The $\mathrm{x}$-rays diffractogram of the kaolin clay $(\mathrm{K})$ and the metakaolin (MK) [23].

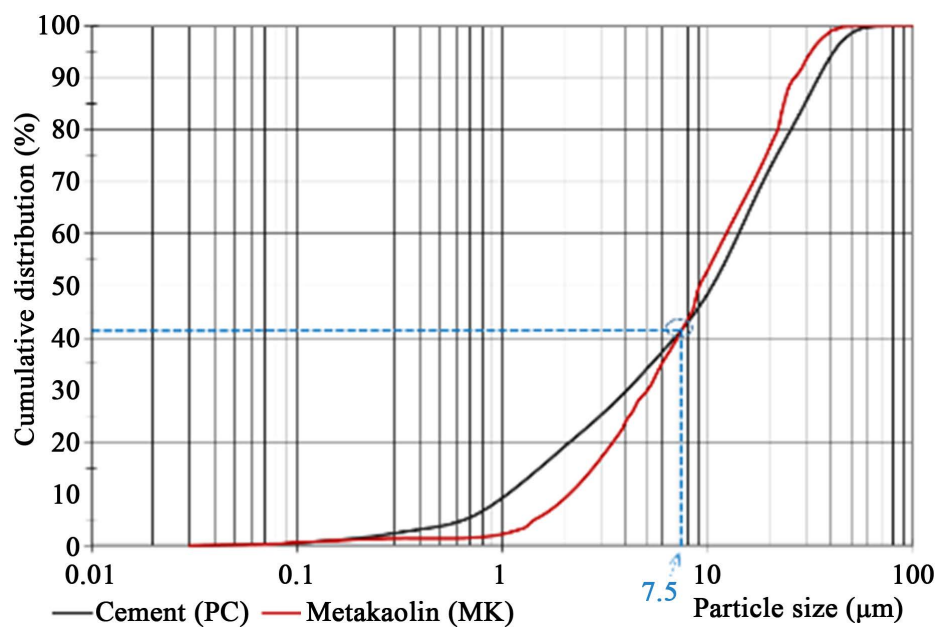

Figure 4. The grain size distribution of metakaolin and cement used in the study [23]. 
$\mathrm{mm}$ diameter and $100 \mathrm{~mm}$ height. Samples to be tested for acid attack resistance were immediately placed in saturated slaked-lime water at demolding, 24 hours after casting, to prevent the Portlandite release.

Mortars mixes designs were performed using materials ratios indicated by individual European standards: EN 196-3 [21] for physical setting time determination, EN 196-1 [24] for mechanical testing, NF P 15-433 [25] for total shrinkage determination and NF P 15-436 [26] for calorimetry. The water to binder $(\mathrm{W} / \mathrm{C}+\mathrm{MK})$ ratio was kept at 0.5 for all samples and 0.27 for the setting time determination. The mortars contained sand at the sand to binder ratio $(\mathrm{S} / \mathrm{C}+\mathrm{MK})$ of 3.0. The detailed mix designs and corresponding standards is shown in Table 2 . The $\mathrm{W} / \mathrm{B}$ ratio in Table 2 refers to the water to binder ratio with binder made of $\mathrm{PC}+\mathrm{MK}$. This ratio was retained from European/French testing standards.

\subsubsection{Experimental Set-Ups and Procedures}

\section{a) Physical properties}

The setting time of a binder corresponds to the time spent from water-binder mixing to the beginning of the setting, which, according to EN 196-3 [21], coincides with a $4 \pm 1 \mathrm{~mm}$ Vicat needle penetration measured from the bottom of the mold. This test was performed on different pastes (MKs-OPC mixes) on a Controlab L0722 automatic Perrier Vicat machine equipped with a standard needle $(1.13 \pm 0.05 \mathrm{~mm}$ diameter and $50 \pm 1 \mathrm{~mm}$ height). The initial setting time and final setting time of the binders was deduced from recorded penetrations over 10 minutes spaced time automatically recorded data over a six hours' period.

The hydration heat of MKs-PC mortars was studied by the Semi-adiabatic Langavant calorimetry according to the NFP 15-436 [26] with the experimental set-up shown in Figure 5. The measures were performed on a L0071.1 Controlab Langavant calorimeter in laboratory conditions set at $20^{\circ} \mathrm{C}$ and $60 \%$ relative humidity. One part of cement and three parts of sand were mixed with water

Table 2. Mix designs for experimental testing over PC-MK mortars.

\begin{tabular}{cccccccc}
\hline \multirow{2}{*}{ Tests } & \multicolumn{2}{c}{ Mechanical and durability } & \multicolumn{2}{c}{ Setting time } & \multicolumn{2}{c}{ Hydration Heat } \\
\hline \multirow{2}{*}{ Mix designs } & \multicolumn{2}{c}{ W/B 0.5 and S/B 3.0 } & \multicolumn{2}{c}{ S/PC + MK 3,0 } & \multicolumn{2}{c}{ W/B 0.5 and S/B 3.0 } \\
\cline { 2 - 8 } & PC [g] & MK [g] & SP [\%] & PC [g] & MK [g] & PC [g] & MK [g] \\
\hline \multirow{2}{*}{$30 \mathrm{MK}$} & 315.0 & 135.0 & 1.0 & 280.0 & 150.0 & 245.0 & 105.0 \\
$25 \mathrm{MK}$ & 337.5 & 112.5 & 1.0 & 300.0 & 100.0 & 262.5 & 87.5 \\
$20 \mathrm{MK}$ & 360.0 & 90.0 & 1.0 & 320.0 & 80.0 & 280.0 & 70.0 \\
$15 \mathrm{MK}$ & 382.5 & 67.5 & 0.5 & 340.0 & 60.0 & 297.5 & 52.5 \\
$10 \mathrm{MK}$ & 405.0 & 45.0 & 0.5 & 360.0 & 40.0 & 315.0 & 35.0 \\
$00 \mathrm{MK}$ & 450.0 & 0.0 & 0.5 & 400.0 & 0.0 & 350.0 & 0.0 \\
\hline
\end{tabular}




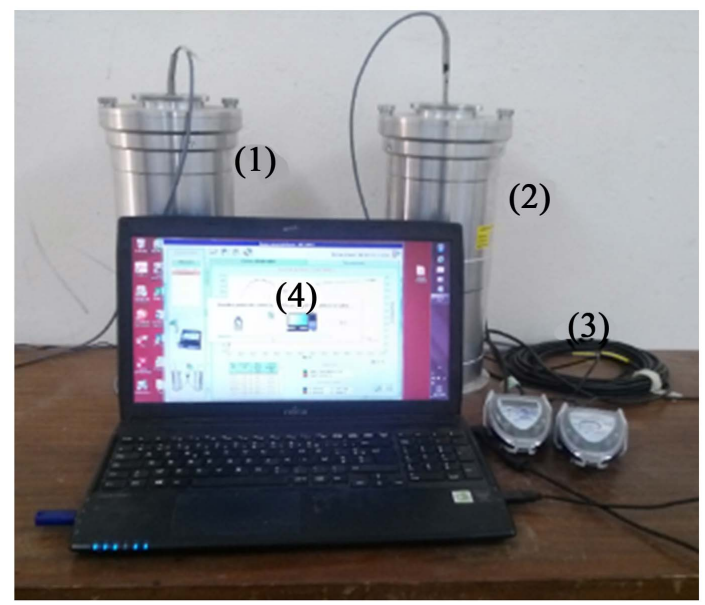

Figure 5. Hydration heat test with, dewar flask (1), data receptors (2)-(3) and data treatment software (4).

$(\mathrm{S} / \mathrm{C}+\mathrm{MK}=3)$ and transferred immediately into a Dewar vacuum flask protected by a rigid aluminium box covered by an insulating plug. The temperature evolution of the sample with regard to a non-evolving reference material was recorded by an integrated thermometer and send to a computer through Cemtech Controlab software.

The total shrinkage of MKs-PC mortars has been measured in accordance with the NF P 15-433 standard [25]. The experimental configuration is shown in Figure 6. The mortars were cast into $40 \times 40 \times 160 \mathrm{~mm}^{3}$ three gangs' molds and equipped with firmly fixed metal ends. These specimens were demolded the following 24 hours and air-cured in laboratory conditions. The variations in lengths of specimens were recorded using a E0078/M Controlab numerical machine of a $\pm 0.001 \mathrm{~mm}$ precision.

The water capillarity absorption test was performed on mortars placed in an arrangement to allow unidirectional flow from the bottom of specimens. The specimens coated with enamel were placed into water at a $5 \pm 1 \mathrm{~mm}$ height and the change in weight was recorded as a function of time over a 24 hours' period. This test was performed upon 28 days' water-cured samples according to the directions of the AFPC-AFREM 199 [27].

\section{b) Mechanical properties}

The tested $40 \times 40 \times 160 \mathrm{~mm}^{3}$ prismatic samples were placed on the flexure testing machine on two $10 \mathrm{~mm}$ roller supports with $100 \mathrm{~mm}$ spacing. The third mid-spaced roller transmits the force from the machine hydraulic system set to $50 \pm 10 \mathrm{~N}$ per second still rupture. The flexural tensile strength of sample was then deduced from the Equation (1).

$$
\begin{gathered}
R_{f}=\left(1.5 * F_{f} * L\right) /\left(b^{3}\right) \\
R_{c}=F_{c} / 1600
\end{gathered}
$$

Within $b$ : specimens cross section of $40 \mathrm{~mm}$ and $L$ : Roller supports spacing of $100 \mathrm{~mm}, F_{f}$ the recorded rupture force and $R_{f}$ the flexural stress. $R c$ is the ulti- 


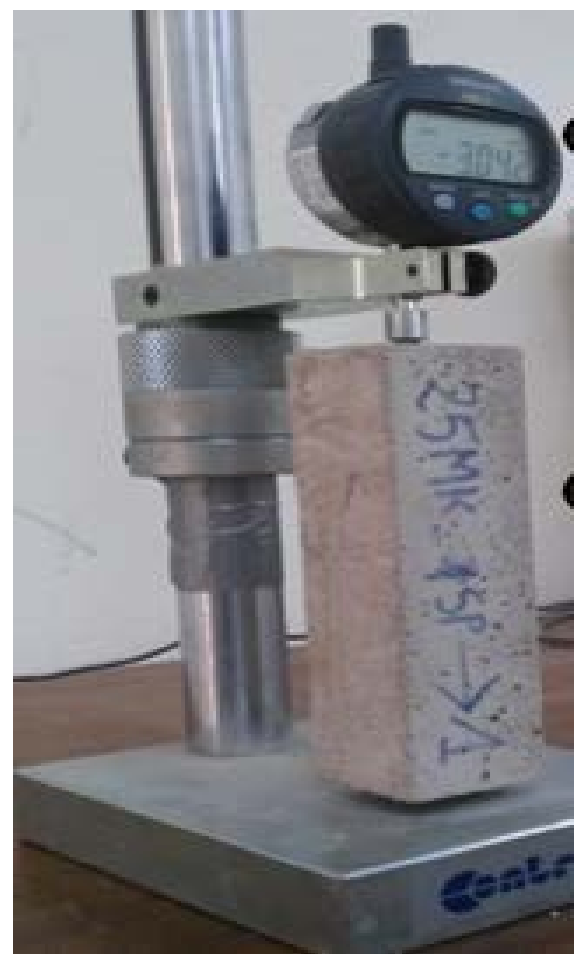

Figure 6. Total shrinkage test.

mate compressive strength in $\mathrm{MPa}, F_{\mathcal{C}}$ the maximum load at rupture in Newtons and 1600 corresponding to the surface area of the platens $\left(\mathrm{mm}^{2}\right)$.

The compressive strengths tests were conducted over the two halves resulting from the flexion test and calculated according to the Equation (2). The Figure 7 shows the testing principle and the experimental for the three-bending points flexure test.

The dynamic modulus of elasticity $\left(E_{d y n}\right)$ was measured using the Portable Ultrasonic Nondestructive Digital Test (PUNIDT) Lab-Bera Test apparatus (Figure 8). A small amount of gel was applied on transducers and tested specimen ends to ensure a perfect contact between transducers and tested specimens. The calibration of the machine is first ensured using a calibration rod of $25.4 \mu \mathrm{m}$ under $250 \mathrm{kHz}$. After calibration, the tested specimens were mounted on apparatus prepared to ensure the application of the same pressure on transducers. The $E_{d y n}$ was deducted from the pulse velocity using the Equation (3).

$$
E_{d y n}=\rho_{d} * V^{2} *(1+v)(1-2 v) /(1-v)
$$

where $E_{d y n}$ is the dynamic Young modulus in $\mathrm{kg} / \mathrm{m}^{2} ; v$ the Poisson coefficient and $V$ the P-wave velocity through specimens in $\mathrm{m} / \mathrm{s}$.

\section{c) Durability properties}

Acid attacks test was conducted by measuring the weight change as function of time of immersion in an acid solution of $5 \% \mathrm{H}_{2} \mathrm{SO}_{4}$. The cylindrical mortar specimens ( $4 \mathrm{~mm}$ of diameter and $6 \mathrm{~mm}$ of height) were cured for 28 days in lime water. They were washed with clean water the test date and submerged in 

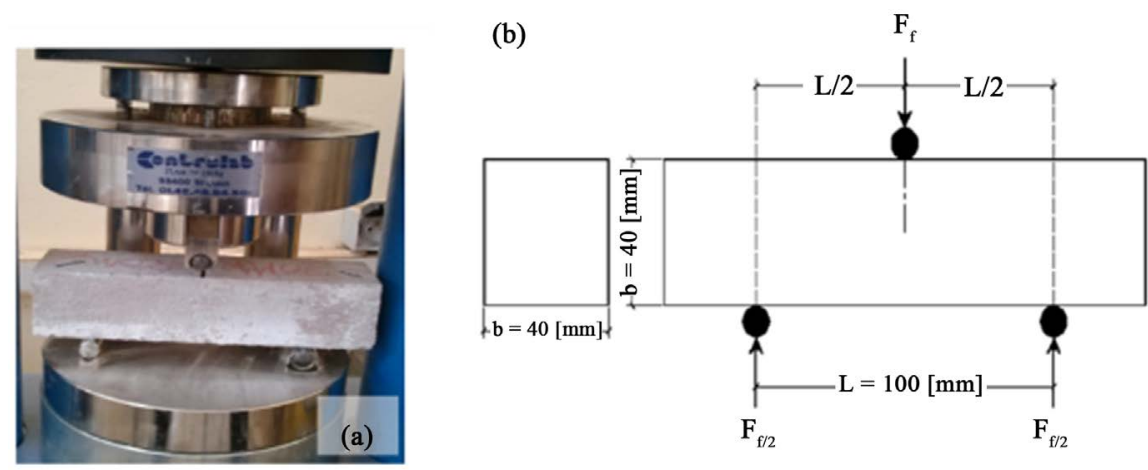

Figure 7. Testing set-up (a) and principle (b) for three-points bending flexural strength.

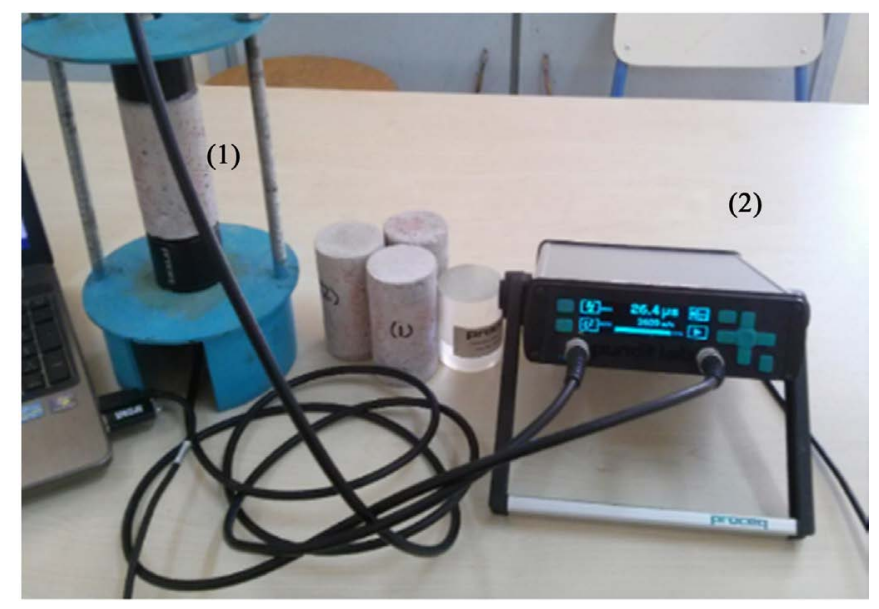

Figure 8. Ultrasonic pulse velocity testing experimental setup-Pundit: (1) tested specimen between transducers on the experimental setup; (2) Pundit apparatus digital pulse recorder.

the acid solution. The change in weight of specimens was recorded after 1, 3, 7, 14, 21, 28 and 35 days of immersion. The acidic solution was renewed to keep the $\mathrm{pH}$ constant for the duration of the test. The evolution of weight change over 14 days was recorded.

The Drying-Wetting cycles test can be defined as an alternating series of soaking at $20^{\circ} \mathrm{C}$ for 5 hours followed by a drying period of 42 hours at $71^{\circ} \mathrm{C}$ to which are subjected the studied materials. The tested specimens the variation is in compressive strengths before and after 12 cycles of drying-wetting. This test, performed according to the ASTM D 559 standard [28], was used to simulate possible local environmental constraints to which can be subjected the MKsOPC cementitious materials.

\section{Results and Discussions}

\subsection{Physical Characterization}

\subsubsection{Initial and Final Vicat-Setting}

The setting times measured on the Vicat apparatus are confined in Table 3 along with the Marsh Cone flow results. The initial setting times of cements in- 
Table 3. Marsh cone flow, initial and final setting time of MK blended binders.

\begin{tabular}{cccc}
\hline Mortar Mixes & Marsh Cone Flow $(\mathrm{sec})$ & Initial setting time $(\mathrm{min})$ & Final setting time (min) \\
\hline 0 MK/PC & $33.9 \pm 0.70$ & 138.2 & 246.2 \\
$10 \mathrm{MK}$ & $51.09 \pm 0.34$ & 142.5 & 236.5 \\
$15 \mathrm{MK}$ & $62.95 \pm 2.75$ & 153.38 & 236.36 \\
$20 \mathrm{MK}$ & $84.45 \pm 1.03$ & 158 & 236 \\
$25 \mathrm{MK}$ & $104.05 \pm 1.83$ & 178.16 & 246.16 \\
\hline
\end{tabular}

corporating MKs are higher than those observed on reference paste without MK. Brooks and Johari [29] and Badogiannis et al. [30] have observed similar results. This behavior is attributable to the dilution effect resulting from the decrease of the amount of cement. In fact, less cement implies less clinker which in turn implies less C3S, the clinker phase with the most rapid hydration rate. A direct decrease in this clinker phase associated with $\mathrm{C} 3 \mathrm{~A}$, could explained the observed retardation in setting of MKs modified.

This effect of decrease of setting time could constitute an advantage in that it could reduce the setting time and hence reduce plastic shrinkage potential for binder containing amount of MK at rates greater than $10 \%$.

\subsubsection{Semi-Adiabatic Calorimetric Studies}

Observed results are confined in the Figure 9. The calculation of the hydration heat is done through the Equation (4). The exact specific heat/ thermal capacity is an essential input for accurate results. Available literature values could be used however, for realistic comparative study, the overheating of studied samples with reference to a non-evolving material, was analyzed.

$$
q(t)=C / m_{c} \theta+C / m_{c} \int_{0}^{t} \alpha \times \theta \mathrm{d} t
$$

where $C$ is the heat capacity of the binder, mc the mass of the binder, $\theta$ the recorded heat and $\alpha$ the calorimeter calibration factor.

As expected, the maximum overheat was released for $25 \% \mathrm{MK}$ with $27.3^{\circ} \mathrm{C}$ which corresponds to temperatures around $54.3^{\circ} \mathrm{C}$. Temperatures around $58^{\circ} \mathrm{C}$ $60^{\circ} \mathrm{C}$ for $10 \%-30 \%$ were observed by Frias et al. [31]. These results differ from previous calorimetry studies conducted by Jean Ambroise [32]. He has found maximum temperatures of $49^{\circ} \mathrm{C}$ for $10 \% \mathrm{MK}$. This is a typical situation where the dilution effect can be compensated by the pozzolanic reactions. In, fact, although these results differ, they both refer to the percentage of MK which has produced the highest compressive strengths at 28 days of testing. Hence, the amount of overheating can be linked to the degree of strength development.

\subsubsection{Total Shrinkage}

The shrinkage of samples was measured in a $20^{\circ} \mathrm{C}$ and $60 \% \mathrm{RH}$ room for 15 days. Measures were taken for 3 specimens twice a day. Observed results are 


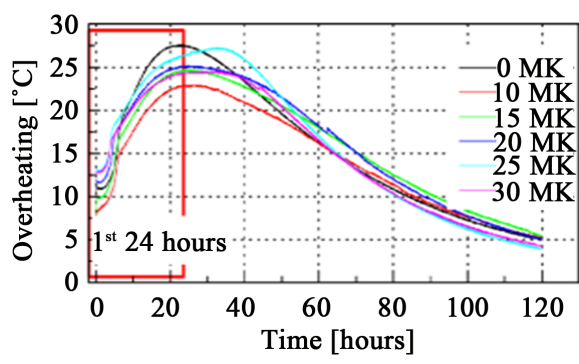

(a)

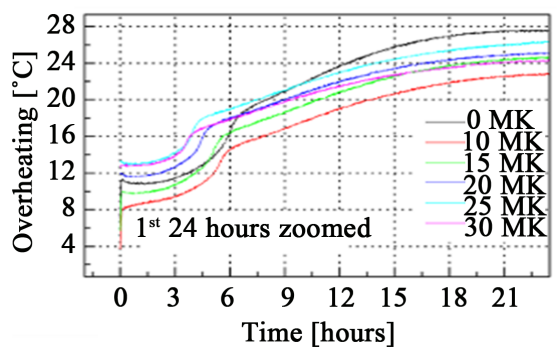

(b)

Figure 9. Hydration heat results: (a) overheating over 5 days and (b) the overheating over the first 24 hours.

presented in the Figure 10 and Figure 11. The influence of MK over shrinkage of the mortars is clearly displayed. The reference mortars show a very rapid increase in shrinkage after 24 hours of approximately 1.9 times those of mortars with $10 \% \mathrm{MK}$. This ratio increases as the amount of MK increases to reach 7.16 times the shrinkage value recorded for mortars with $30 \%$ MKs. The rapid pace of shrinkage increase ceases after 48 hours to reach relatively stable values. At all measuring dates, the reference mortars recorded values of shrinkage at least twice higher than the most shrinking specimens containing MKs (10\% MKs). Brooks and Megan [29] in their studies have noted identical behavior with the total shrinkage reduced as the MK incorporation rate increased for a 200 days period. They have noticed that the drying shrinkage was more influenced with a reduction of over $50 \%$ with reference to the PC mortars. In addition, a reduction effect over chemical and autogenous shrinkage was observed for compositions with $15 \% \mathrm{MK}$ and above [33]. The effect over total shrinkage observed by Brooks and Megan were attributed to the reduction of evaporable water while that over the formation of novel hydrate phases.

The results shown in Figure 10 were confirmed by analyzing shrinkage values as a function of the weight change. The results in Figure 11 show higher shrinkage values for reference mortars at the same weight change as for MK modified mortars. At 5\% water loss, the recorded shrinkage was of approximately $910 \mathrm{mi}-$ crostrains for reference mortar, 280 microstrains for $10 \%$ and 15\% MK, $140 \mathrm{mi}-$ crostrains for $20 \%$ and $25 \%$ MK. For the same water loss (5\%), mortars incorporating 30\% MKs displayed a shrinkage of 52.0 microstrains which corresponds to 17.5 times lower than the reference mortar values. In addition, the mortars modified with MKs have reached water losses of at least $5.6 \%$ and the maximum shrinkage recorded was 600 microstrains within the measuring period while the reference mortar has reached shrinkages of 986 microstrains with maximum water loss of $5 \%$.

\subsubsection{Capillarity Water Absorption}

The effect of MK incorporations over sorptivity of MK blended mortars in terms of the capillary water absorption (CWA) is shown in Figure 12. The results show that mortars containing MK, generally display lower CWA compared to 


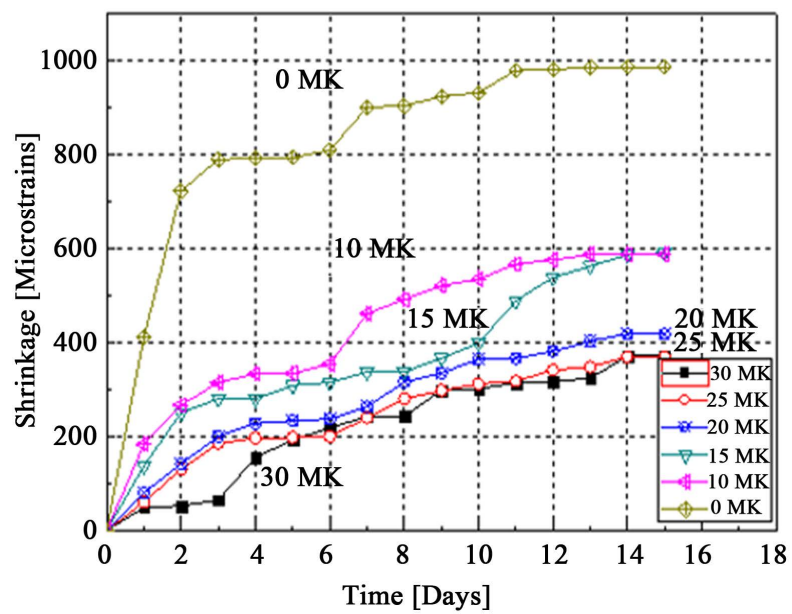

Figure 10. Effect of MK on total shrinkage of mortars after 28 days of moist curing: Total shrinkage as function of time.

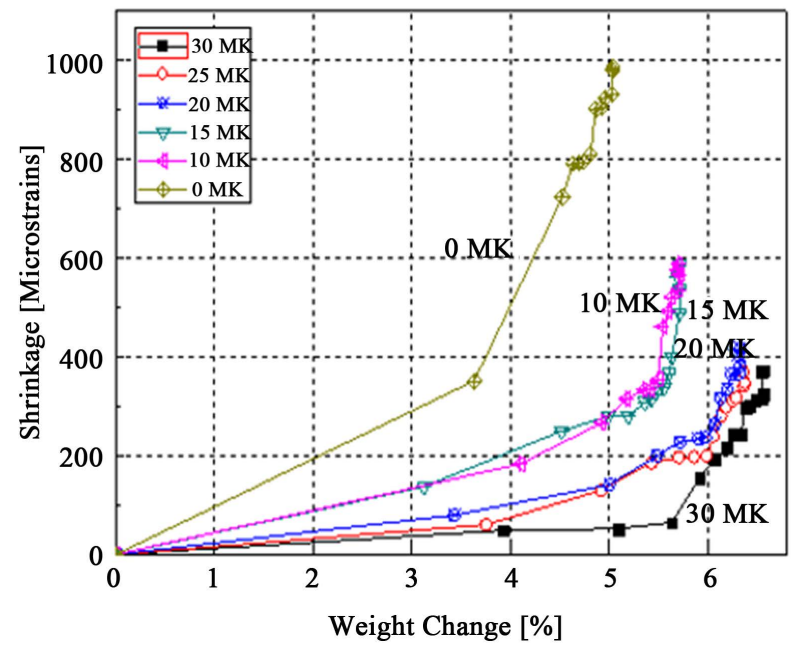

Figure 11. Effect of MK on total shrinkage of mortars after 28 days of moist curing: total shrinkage as function of weight loss.

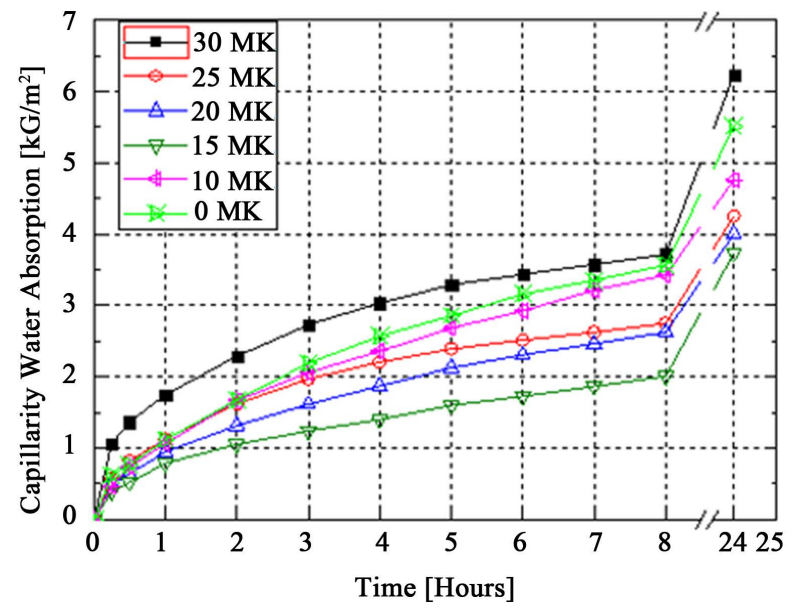

Figure 12. Sorptivity/water capillary rise of MKs-OPC mortars after 28 days of curing. 
the PC reference mortars, except for mortars incorporating 30\% MK. Mortars with $25 \% \mathrm{MK}$ incorporation have shown a $22.78 \%$ reduction in CWA with regard to the PC mortars. Respectively, reductions of $27 \%$ and $32 \%$ were recorded for $20 \% \mathrm{MK}$ and $15 \% \mathrm{MK}$.

Contrary to all MKs modified mortars, 30\% MKs mortars displayed higher CWA than the PC reference mortars. An increase of $13.14 \%$ of the absorption with regard to the reference mortar at 24 hours was recorded. Nevertheless, this value decreases as shown in Figure 12. It evolved from $56.6 \%$ after the $1^{\text {st }}$ hour to reach $4.27 \%$ at the 8 th hour while other MK blended mortars displayed relatively stable decreases afterward. These results contradict those obtained by Courard et al. [34] who observed constant values around $0.30 \mathrm{~g} / \mathrm{cm}^{2}$ for $0 \%, 5 \%$, $10 \%, 15 \%$ and $20 \%$

MK, with a slight decrease of WCA for $20 \%$ MK. In their studies, Shekarchi et al. [35] have noted an improvement of $28 \%$ in water absorption at $15 \% \mathrm{MK}$ after 28 days of curing was recorded. These results confirm best WCA improvements for $15 \%-20 \% \mathrm{MK}$ incorporations. The results recorded in Figure 9 show lowest WCA at $3.5 \mathrm{~kg} / \mathrm{m}^{2}$ for $15 \% \mathrm{MK}$ at 24 hours.

\subsection{Mechanical Characterization}

\subsubsection{Compressive and Three-Point Bending Strengths}

The evolution of compressive strengths of mortars with time and MK incorporations are shown in Figure 13. Observed results have shown that mortars without MK have lower strengths. At early age (2 days), mortars modified with MK at all

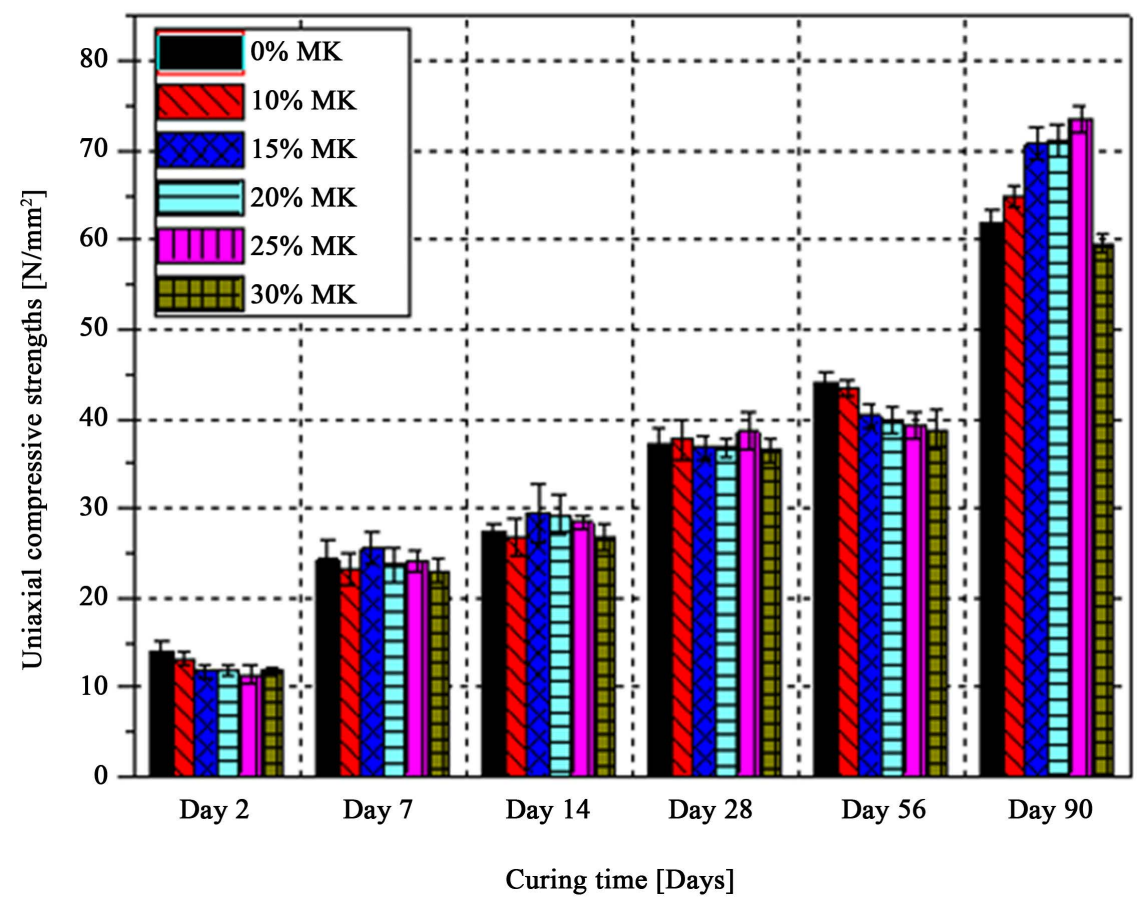

Figure 13. Compressive strengths of MK containing mortars as function of water curing time. 
ratios of substitution display compressive strengths lower than those of the OPC reference mortars. This can be explained through the action mechanism of MKs. In fact, after 2 days of curing, the hydration Portlandite level remains insufficient for the pozzolanic reactions of MK to proceed at high rate. At this stage, the filler effect and the acceleration of OPC reactions are predominant [36].

On the contrary, at 7 and 14 days, mortars containing MK display higher compressive strengths than the reference mortar without MK. They are 5.0\% and $7.5 \%$ higher respectively at 7 and 14 days. The strength development of MK containing mortars progresses with curing age. At 28, 56 and 90 days of curing, the MK containing mortars show better compressive strengths with regard to reference mortars with an activity index of $103.56 \%$ for $25 \%$ MK mortars at 28 days, $108.27 \%$ for $15 \%$ MK mortars at 56 days and $118.61 \%$ for $25 \%$ MK mortars at 90 days of curing.

The observed tensile strengths results have shown little influence of MK substitution rate at all ages of curing. In fact, at all curing ages of testing, the tensile strengths varied in an average range $\pm 0.5 \mathrm{MPa}$. The results are not presented here.

\subsubsection{Ultrasonic Pulse Dynamic Young Modulus}

The Figure 14 records the observed results for the dynamic modulus of elasticity of tested mortars after 28 days of curing in a $20^{\circ} \mathrm{C}$ and $60 \% \mathrm{RH}$ laboratory condition room. The analysis of $E d y n$ of mortars incorporating varying amount of MK show modulus of elasticity generally closer or even slightly higher (for $10 \%$ and $20 \% \mathrm{MK}$ ) that that of the reference mortar. Metakaolins containing $25 \%$ and $30 \%$ MK have displayed the lowest moduli. Nevertheless, the influence of the ra-

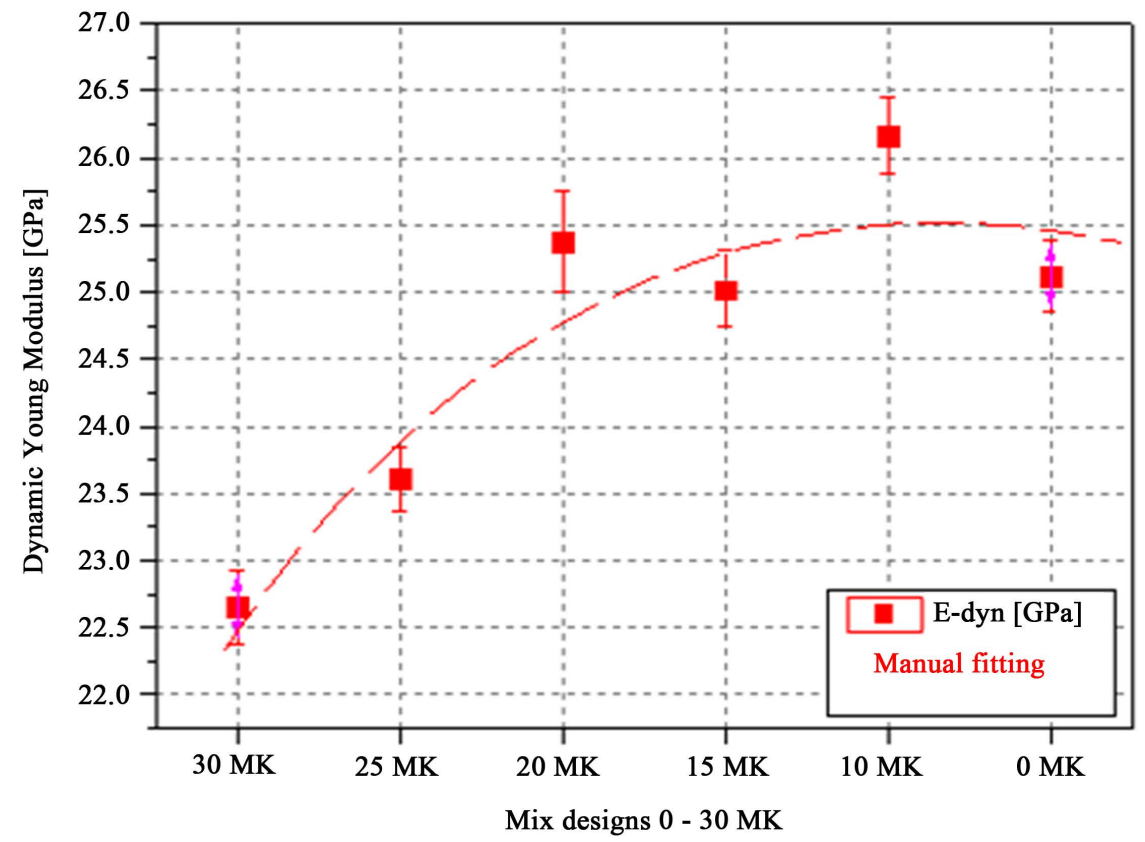

Figure 14. The dynamic modulus of elasticity of MK containing mortars. 
tio of $\mathrm{MK}$ is very little and vary within a $\pm 1.414 \mathrm{GPa}$ limits. Similar results have been found by Khatib et al. [37] in their study over concrete containing metakaolin.

\subsection{Durability}

\subsubsection{Acid Attacks.}

The Figure 15 shows the evolution of weight loss of the studied specimens soaked in a $5 \% \mathrm{H}_{2} \mathrm{SO}_{4}$ acid for a continuous period of 28 days. These results generally display decreasing weights for all specimens as function of time. This weight loss is attributable to the lixiviation of binder's hydration products as function of acid exposure period [38] [39]. The analysis of the results shows that at the first and third day of acid attack, the reference mortar without MK displays higher weight losses with reference to the MK containing mortars. The difference in weight loss evolved from very slight (barely noticeable) after 24 hours to reach $2 \%$ at 7 days for $25 \%$ MK compared to the reference mortars.

The improvement acid resistance conferred to the mortars by incorporating MK at increasing proportions is displayed by the form of the diagrams (Descending stairs: i.e. increasing the amount of MK led to the increasing acid resistance to the acid lixiviation effects). This resistance improvement was attributed to the consumption of $\mathrm{CH}$ soluble phase of the cement matrix by reactive silica and alumina of MK.

The general higher weight loss recorded of all samples (illustration on Figure 16), is a result of a double damaging effect of sulfuric acid. The sulfuric acid apart from generating lixiviation of the cementitious materials, it generates the ettringite by reacting with gypsum, a salt resulting from the reaction of the

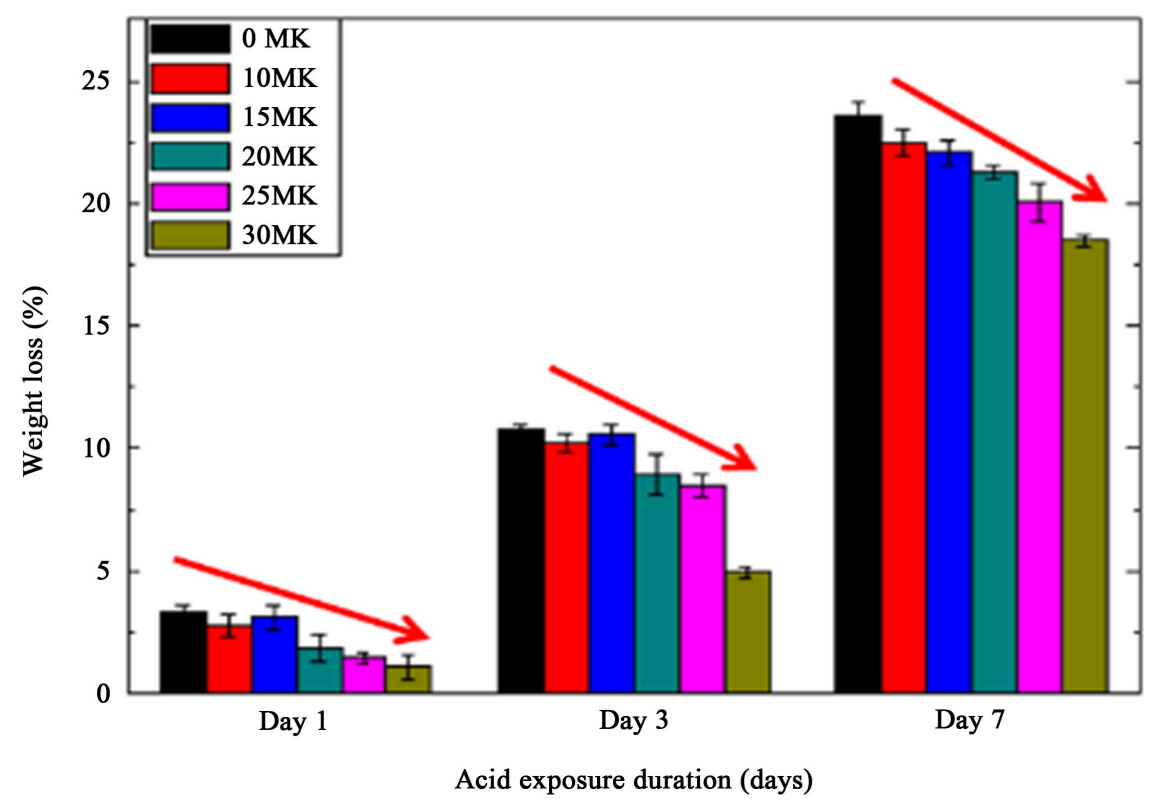

Figure 15. Acid attacks resistance of MKs-OPC mortars: evolution of weight loss of MKs-OPC. 


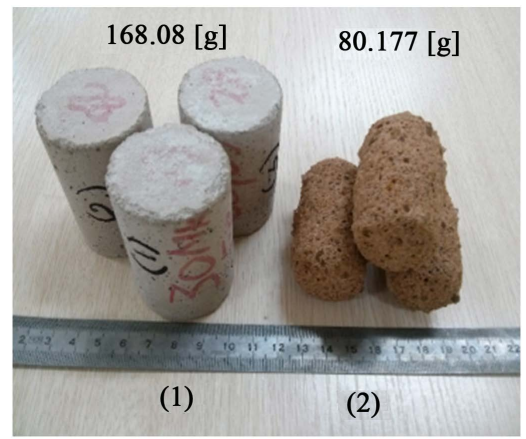

Figure 16. Visual examination of acid lixiviation for 30\% MK mortars: (1) specimens before and after the acid exposure period of 28 days.

acid with $\mathrm{CH}$. This ettringite lead to expanding and creates micro-cracks that accelerate further acid lixiviation [39] [40].

\subsubsection{Wetting-Drying Cycles (Accelerated Ageing)}

The specimens tested have undergone 12 successive cycles of 05 hours wetting at $20^{\circ} \mathrm{C}$ and 42 hours heating at $71^{\circ} \mathrm{C}$. The visual analysis of samples has revealed the development of mini-cracks observable on samples immersed in water after wetting-drying (W.D) cycles. The analysis of observed results (Figure 17) has shown an increase of around $30 \%$ in compressive strengths for the reference OPC mortars and 10\% MK mortars while the remaining of MK mortars displayed decreases, with $15 \% \mathrm{MK}$ and 25\% MK loosing respectively $32 \%$ and $26.5 \%$ of their strengths.

\section{Conclusions}

Analysis of the previously discussed results presented in this paper has led to the following conclusions.

- It has been shown through this study that the kaolin clay heat-treated at $700^{\circ} \mathrm{C}$ for 3 hours presented a chemical composition principally made of silica and alumina. The X-ray results have confirmed the amorphous state of the dehydrated material.

- The initial setting times of metakaolin blended cements were found higher than those of the reference Portland Cement. This delayed setting was observed to grow as the MK/PC ratio increased and was attributed to the dilution effect. The influence of metakaolin over the hydration heat was measured using the Langavant calorimetry, and for more accurate comparative analyses, overheating was recorded for analysis. The maximum overheating was recorded for reference Portland Cement $\left(27.6^{\circ} \mathrm{C}\right)$. The general kinetics of hydration heat evolution was nevertheless found identical to that of the Portland Cement. The incorporation of MK has proved to have considerable influence over total shrinkage. The total shrinkage was reduced by at least half by incorporating $\mathrm{MK}$ and for the whole period of study. The increase of MK/PC ratio, contributed to increasingly lower shrinkage values. 


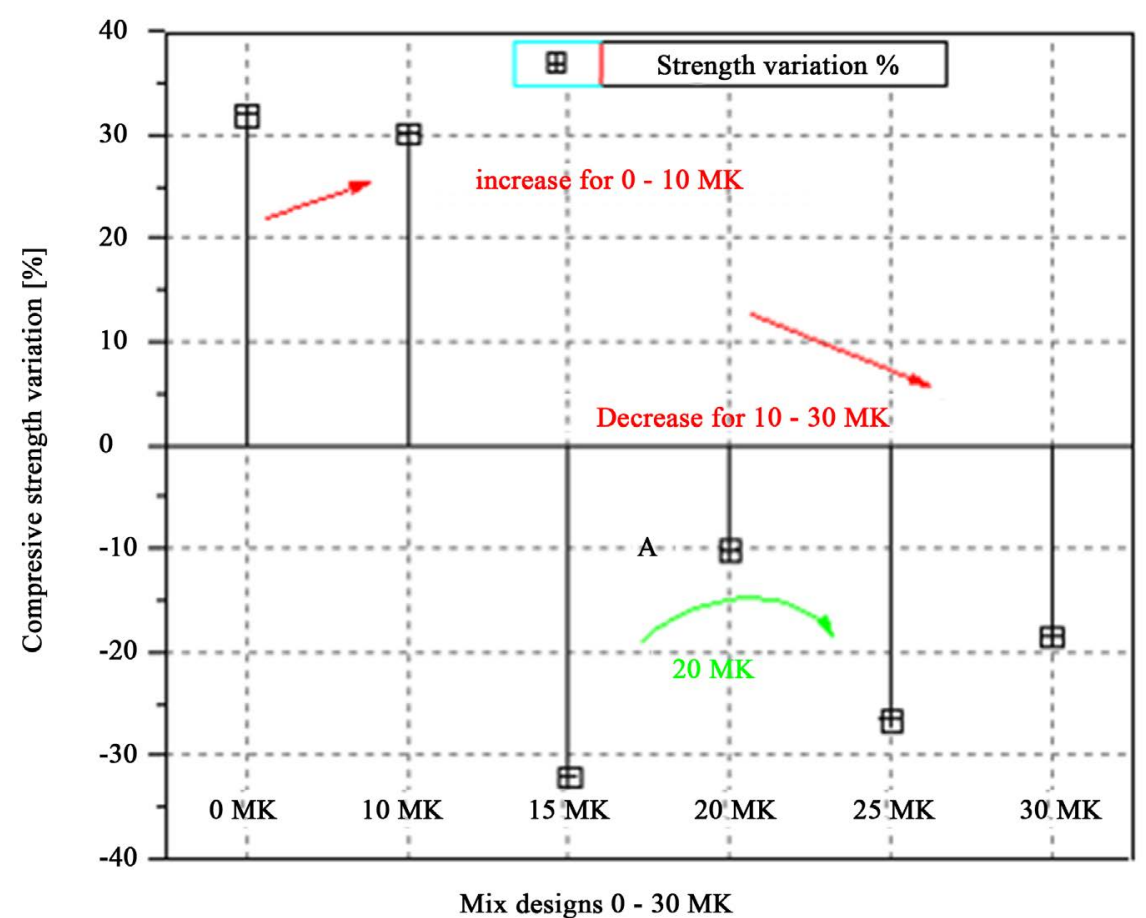

Figure 17. The compressive strengths variations after the 12 cycles of wetting and drying (W-D).

- The incorporation of MK has proven to reduce the compressive strengths at 2 and 7 days of curing (the activity indexes below $100 \%$ for all MK incorporation rates). However, for 14, 28, 56 and 90 days of curing, MK containing mortars have displayed better compressive strengths (107.5\% AI for $15 \mathrm{MK}$, $103.5 \%$ for $25 \mathrm{MK}$ and $108.25 \%$ for $15 \mathrm{MK}$ respectively at 14,28 and 56 days of curing). The incorporation of $\mathrm{MK}$ at a ratio of $25 \%$, has led to a compressive strength $18 \%$ higher than the reference mortar at 90 days of curing. The incorporation of MK significantly improves compressive strengths in the long run (90 days) and it is concluded that for 28 days, the replacement of cement by $25 \% \mathrm{MK}$ would provide at least equivalent compressive strengths as the PC without significantly influencing other mechanical properties (flexural tensile and $\left.E_{d y n}\right)$.

- Acid attacks results were expressed in terms of weight loss corresponding to the lixiviation of hydration products of the studied materials. Observed results have shown that remarkable improvement against acid attacks was achieved for metakaolin incorporations greater than 15\% MK (i.e. 20\%, 25\%, and 30\% $\mathrm{MK})$. It was concluded that the acid attack resistance grows with the increase of MK due to its double effect of filler and pozzolan. The Wetting-Drying (WD) testing has proven $\mathrm{MK}$ mortars to be highly vulnerable to brutal heat changes. The $25 \% \mathrm{MK}$ mortar has displayed a decrease in compressive strength of $26 \%$ after 12 cycles of wetting $\left(20^{\circ} \mathrm{C}\right.$ for 05 hours)-drying ( $71 \mathrm{C}$ for 42 hours). 
The incorporation of MK from SAABA has shown encouraging results with regard to physical and mechanical results. The W-D heat results have shown non negligible fragility with regard to abrupt change of temperature $\left(71^{\circ} \mathrm{C}\right.$ $20^{\circ} \mathrm{C}$ ). Nevertheless, the unquestionable industrial potential of this material would significantly contribute to the valorization of clayey materials in the construction industry in Burkina Faso.

\section{Acknowledgements}

The authors appreciate the financial support provided by the Deutscher Akademischer Austauschdienst (DAAD-Germany). Special gratitude also to the entire LEMC team.

\section{References}

[1] The, S.H., Wiedmann, T., Castel, A. and de Burgh, J. (2017) Hybrid Life Cycle Assessment of Greenhouse Gas Emissions from Cement, Concrete and Geopolymer Concrete in Australia. Journal of Cleaner Production, 152, 312-320.

[2] Millogo, Y., Hajjaji, M., Ouedraogo, R. and Gomina, M. (2008) Cement-Lateritic Gravels Mixtures: Microstructure and Strength Characteristics. Construction and Building Materials, 22, 2078-2086.

[3] Millogo, Y., Morel, J.-C., Traoré, K. and Ouedraogo, R. (2012) Microstructure, Geotechnical and Mechanical Characteristics of Quicklime-Lateritic Gravels Mixtures Used in Road Construction. Construction and Building Materials, 26, $663-$ 669.

[4] Ouedraogo, E., Coulibaly, O., Ouedraogo, A. and Messan, A. (2015) Mechanical and Thermophysical Properties of Cement and/or Paper (Cellulose) Stabilized Compressed Clay Bricks. Journal of Materials and Engineering Structures, 2, 68-76.

[5] Pare, S., et al. (2012) Heavy Metal Removal from Aqueous Solutions by Sorption Using Natural Clays from Burkina Faso. African Journal of Biotechnology, 11, 10395-10406. https://doi.org/10.5897/AJB11.3735

[6] Kabre, T.S., Traore, K. and Blanchart, P. (1998) Mineralogy of Clay Raw Material from Burkina Faso and Niger Used for Ceramic Wares. Applied Clay Science, 12, 463-477.

[7] Ilić, B.R., Mitrović, A.A. and Miličić, L.R. (2010) Thermal Treatment of Kaolin Clay to Obtain Metakaolin. Hemijska Industrija, 64, 351-356. https://doi.org/10.2298/HEMIND100322014I

[8] Zhang, M.H. and Malhotra, V.M. (1995) Characteristics of a Thermally Activated Alumino-Silicate Pozzolanic Material and Its Use in Concrete. Cement and Concrete Research, 25, 1713-1725.

[9] Kostuch, J.A., Walters, V. and Jones, T.R. (2000) High Performance Concretes Incorporating Metakaolin: A Review. Concrete, 2, 1799-1811.

[10] Moodi, F., Ramezanianpour, A.A. and Safavizadeh, A.S. (2011) Evaluation of the Optimal Process of Thermal Activation of Kaolins. Scientia Iranica, 18, 906-912.

[11] Shvarzman, A., Kovler, K., Grader, G.S. and Shter, G.E. (2003) The Effect of Dehydroxylation/Amorphization Degree on Pozzolanic Activity of Kaolinite. Cement and Concrete Research, 33, 405-416. 
[12] Murat, M. (1983) Hydration Reaction and Hardening of Calcined Clays and Related Minerals. I. Preliminary Investigation on Metakaolinite. Cement and Concrete Research, 13, 259-266.

[13] Murat, M. (1983) Hydration Reaction and Hardening of Calcined Clays and Related Minerals: II. Influence of Mineralogical Properties of the Raw-Kaolinite on the Reactivity of Metakaolinite. Cement and Concrete Research, 13, 511-518.

[14] Murat, M. and Comel, C. (1983) Hydration Reaction and Hardening of Calcined Clays and Related Minerals III. Influence of Calcination Process of Kaolinite on Mechanical Strengths of Hardened Metakaolinite. Cement and Concrete Research, 13, 631-637.

[15] Ambroise, J. (1984) Elaboration de liants pouzzolaniques à moyenne température et étude de leurs propriétés physico-chimiques et mécaniques.

[16] Okada, K., ŌTsuka, N. and Ossaka, J. (1986) Characterization of Spinel Phase Formed in the Kaolin-Mullite Thermal Sequence. Journal of the American Ceramic Society, 69, C-251. https://doi.org/10.1111/j.1151-2916.1986.tb07353.x

[17] Percival, H.J., Duncan, J.F. and Foster, P.K. (1974) Interpretation of the KaoliniteMullite Reaction Sequence from Infrared Absorption Spectra. Journal of the American Ceramic Society, 57, 57-61. https://doi.org/10.1111/j.1151-2916.1974.tb10813.x

[18] Chakraborty, A.K. (2003) DTA Study of Preheated Kaolinite in the Mullite Formation Region. Thermochimica Acta, 398, 203-209.

[19] San Nicolas, R. (2011) Approche Performantielle des bétons avec métakaolins obtenus par calcination flash. Université de Toulouse, Université Toulouse III-Paul Sabatier.

[20] Togo Heidelberg Cement Africa. http://www.hcafrica.com/en/togo

[21] EN 196-3 (2008) Méthodes d'essais des ciments-Partie 3: Détermination du temps de prise et de la stabilité. CEN.

[22] NFP 94-056 (1996) Sols: Reconnaissance et essais-Analyse granulométriqueMéthode par tamisage á sec après lavage. AFNOR.

[23] Sore, S.O., Messan, A., Prud'homme, E., Escadeillas, G. and Tsobnang, F. (2016) Synthesis and Characterization of Geopolymer Binders Based on Local Materials from Burkina Faso-Metakaolin and Rice Husk Ash. Construction and Building Materials, 124, 301-311.

[24] NF EN 196-1 (2008) Méthodes d'essais des ciments-Partie 1: Détermination des résistances mécaniques. AFNOR.

[25] NF P 15-433 (1994) Méthodes d'essais des ciments-Détermination du retrait et du gonflement. AFNOR.

[26] NFP 15-436 (1988) Binders-Measuring the Hydration Heat of Cements by Means of Semi-Adiabatic Calorimetry (Langavant Method). AFNOR.

[27] AFPC-AFREM (1998) Taux d'absorption par succions capillaires.

[28] ASTM D 559 (1996) Standard Test Methods for Wetting and Drying. ASTM.

[29] Brooks, J.J. and Megat Johari, M.A. (2001) Effect of Metakaolin on Creep and Shrinkage of Concrete. Cement and Concrete Composites, 23, 495-502.

[30] Badogiannis, E., Kakali, G., Dimopoulou, G., Chaniotakis, E. and Tsivilis, S. (2005) Metakaolin as a Main Cement Constituent. Exploitation of Poor Greek Kaolins. Cement and Concrete Composites, 27, 197-203.

[31] Frias, M., De Rojas, M.S. and Cabrera, J. (2000) The Effect That the Pozzolanic Reaction of Metakaolin Has on the Heat Evolution in Metakaolin-Cement Mortars. 
Cement and Concrete Research, 30, 209-216.

[32] Ambroise, J., Maximilien, S. and Pera, J. (1994) Properties of Metakaolin Blended Cements. Advanced Cement-Based Materials, 1, 161-168.

[33] Khatib, J.M. and Wild, S. (1996) Pore Size Distribution of Metakaolin Paste. Cement and Concrete Research, 26, 1545-1553.

[34] Courard, L., Darimont, A., Schouterden, M., Ferauche, F., Willem, X. and Degeimbre, R. (2003) Durability of Mortars Modified with Metakaolin. Cement and Concrete Research, 33, 1473-1479.

[35] Shekarchi, M., Bonakdar, A., Bakhshi, M., Mirdamadi, A. and Mobasher, B. (2010) Transport Properties in Metakaolin Blended Concrete. Construction and Building Materials, 24, 2217-2223.

[36] Wild, S., Khatib, J.M. and Jones, A. (1996) Relative Strength, Pozzolanic Activity and Cement Hydration in Superplasticised Metakaolin Concrete. Cement and Concrete Research, 26, 1537-1544.

[37] Khatib, J.M. and Clay, R.M. (2004) Absorption Characteristics of Metakaolin Concrete. Cement and Concrete Research, 34, 19-29.

[38] Monteny, J., et al. (2000) Chemical, Microbiological, and in Situ Test Methods for Biogenic Sulfuric Acid Corrosion of Concrete. Cement and Concrete Research, 30, 623-634.

[39] Alexander, M., Bertron, A. and De Belie, N. (2013) Performance of Cement-Based Materials in Aggressive Aqueous Environments, 10. Springer, Berlin. https://doi.org/10.1007/978-94-007-5413-3 11

[40] Stark, D. (2002) Performance of Concrete in Sulfate Environments.

\section{Submit or recommend next manuscript to SCIRP and we will provide best service for you:}

Accepting pre-submission inquiries through Email, Facebook, LinkedIn, Twitter, etc. A wide selection of journals (inclusive of 9 subjects, more than 200 journals) Providing 24-hour high-quality service User-friendly online submission system Fair and swift peer-review system Efficient typesetting and proofreading procedure Display of the result of downloads and visits, as well as the number of cited articles Maximum dissemination of your research work

Submit your manuscript at: http://papersubmission.scirp.org/

Or contact ojce@scirp.org 